\title{
In Pompeii and Volterra the Earth Really Trembles: De-Territorialisation, European Art-Cinema, and the Fate of Neorealism in Roberto Rossellini's Journey to Italy and Luchino Visconti's Sandra
}




\section{Resumo}

Este trabalho se utiliza de dois estudos de caso - Viagem to Italy (1953), de Roberto Rossellini e Sandra (1965), de Luchino Visconti para discutir questões políticas, historiográficas e estéticas [que interferem] no relacionamento entre o neo-realismo como cinema da nação italiana e o "cinema de arte europeu" como uma instituição desnacionalizada

\section{Palavras-chave}

cinema, neo-realismo, cinema de arte europeu

\section{Abstract}

This paper uses two case studies, Roberto Rossellini's Voyage to Italy (1953) and Luchino Visconti's Sandra (1965), to discuss the political, historiographic and aesthetic issues informing the relationship between neo-realism as the cinema of the Italian nation and "European art-cinema" as de-nationalized institution.

\section{Key words}

Cinema, neo-realism, European art-cinema 
I n July 1955, Andre Bazin wrote an open letter to Guido Aristarco, influential Marxist critic and editor-in-chief of the Italian journal Cinema Nuovo: The objective of the letter was the aesthetic rehabilitation of Roberto Rossellini, whose "neo-realist" integrity had been challenged by Aristarco. Famously, the Italian critic had rejected the spiritual concessions of Stromboli (1950), The Flowers of St. Francis (1950) and Journey to Italy (1953), concluding that Rossellini's humanism had become providential, and therefore culpably unbound from the particulars of the historical context. Bazin defended Rossellini, in effect positing historical transcendence as propedeutic to a type of realism that observed the human condition in its penetrable totality. Holistically, that is, Bazin defined as "neo-realist" the preoccupation for everything that is within Man, "the description of reality conceived as a whole by a consciousness disposed to see things as a whole"' (Bazin 97). Like Gramsci, however, Aristarco was ill disposed towards the whole of Man, and championed instead a realism of contingencies, with an emphasis laid on the vicissitudes of a given cultural bloc during a specific historical conjuncture. A hyper-cited text, Bazin's letter to Aristarco gets largely: and understandably: summoned in an effort to discern two opposite conceptions of the realist practice: the transcendental and the sociohistorical.

Much less debated, however, is the extent to which Bazin and Aristarco's allegiance to, respectively, totality and particularity may reveal two colliding standpoints vis-à-vis the impact of cosmopolitanism on the specificity of a national film practice. Addressing Aristarco, Bazin-begins apologetically, for the judgment of a foreigner, he concedes, is "apt...to go astray because of the lack 
of familiarity with the context from which a film comes" (94). Hardly could a Frenchman fathom the Italian context, Bazin continues, and it would be "absurd...to instruct Italians in their own cinema" (93). Coming from one formidable promoter of total cinema, these are uncharacteristic claims, rather ceremonious concessions whose ironic tinge, in fact, may suggest the real target of Bazin's polemic: the alleged provincialism of Italian film criticism. The beneficiary of Bazin's defense, in this respect, is neither a particular conception of neo-realism nor Rossellini per se, but rather the Cahiers du Cinéma, whose entitlement to appropriate Rossellini from abroad is sanctioned in Bazin's letter. Ten years after its conception, neo-realism had come of age and gone out into the world, according to Bazin. No longer was the "Italian school of liberation" the exclusive child of the antiFascist Resistance nor, consequently, could the Italian cultural Left retain its status as sole trustee of the neo-realist truth. In sum, the polemic between Aristarco and Bazin was a battle over the custody of neo-realism, marking the movement's transition from leaflet of the indigenous social protester to patrimony of the global student of cinema.

Arguably, Journey to Italy is the archetypal text of this transition, by virtue of the pivotal yet diametrically opposed positions it occupies in the historiographic narratives of the Italian cultural Left and the French Cahiers. As mentioned, Aristarco lamented Rossellini's progression from a laudable historical phase (that of the "war trilogy") to a dubious second phase (that of the "Bergman trilogy") in which the director had treated reality as fixed, immanent category rather than in its historical becoming. The culmination of this second phase, Journey to Italy marked inevitably a finishing point for many Italian Marxists, the moment in which as vital and live contact between national cinema and society, neo-realism was lost.

The Cahiers critics, on the other hand, hailed the humanist attitude of the "Bergman trilogy" as inaugural moment and portal into cinematic modernity, for their phenomenological approach to the realist practice privileged the totality of the existential survey over the particularity of historical analysis. Journey to Italy "opens a breach," says Jacques Rivette, and "all cinema, by pain of death, 
must go through" it (192). According to Eric Rohmer, in turn, Rossellini's film establishes a brand-new conception of sacred realism, by "refus[ing] to illuminate the mechanics of [character's] choice" (207). Namely, the absence of a behaviorist construction obscures psychological geneses and causal explanations, thus safeguarding the mystery of existence. Rohmer praises in particular the closing sequence of Journey to Italy, in which the estranged couple reconciles by way of a miracle. Here, the deity of the omnipotent character is discarded in favor of placing character inertly before God (207).

Galvanized by the suppression of character's voluntarism, the phenomenological faction of the Cahiers du Cinéma could not but applaud the conclusion of Journey to Italy. It is nonetheless remarkable how the Cahiers' philosophical preferences would come to almost single-handedly define the historiographical legacy of neorealism. Several chief characteristics of 1960's modernist cinema, such as the waning of character's control over phenomena and the lack of causal links between character's motivations and actions are conventionally posited as neo-realist patrimonies. In the cinema books of Gilles Deleuze, for example, the formidably modernizing role ascribed to neo-realism resides precisely with the representation of character's powerlessness. In neo-realist films, Deleuze suggests, reality can be endured but not defied, recorded but never engendered by a character.

Whether or not Italian neo-realism was ever conceived under such phenomenological auspices is open to debate, as the polemic between Aristarco and Bazin testifies. It is arguable, however, that the movement got historicized under phenomenological auspices. Accordingly, Rossellini's cinema of the 1950s has come to typify the culmination of an evolutionary assumption of sorts in which earlier neo-realist works are historicized on the basis of their planting the seeds for later developments. Take Bicycle Thieves (Vittorio De Sica, 1948). In seemingly Marxian fashion, the protagonist resorts to theft upon gaining awareness that neither the Union nor the Church will bring about justice: In line with Aristarco's recommendations, the film provides a political-economic analysis of contemporary social structures. Despite phenomenology, the snatching of the bicycle signals 
the necessity to dominate and modify the recorded reality, let alone a refusal to rely on miracles. This is a plausible reading, yet political voluntarism and historical particularity are only partially contemplated in discussions of Bicycle Thieves. By contrast, the phenomenological implications of having the rain bring character's action to a halt are discussed with restless commitment, for they reaffirm the primacy of a transcendental ethics over the mundane-ness of character's motivation.

Largely in light of Rossellini's later work, neo-realism as a whole has been brought up under the sway of totalizing categories such as "modernity," "phenomenology," and "ethics." This has inevitably de-territorialized the movement, whose indigenousness often gets confounded with the launching of a pan-European project: that "new-wave" of aesthetic and thematic conventions that the blanket term "European art-cinema" interpellates en-bloc. Deleuze in particular de-nationalizes neo-realism, endowing it with the paternity of a universally applicable aesthetics of modernity: the "time-image." Like the miracle of God in Journey to Italy, neo-realism strikes categorically in Deleuze's historiography, functioning as incontrovertible grand caesura between classicism and modernity.

This positivist and linear approach, in which the encrustations of the past never subsist within modernity, makes even more irreconcilable the dichotomy between a certain tradition of French film criticism and the Italian cultural Left of the 1950s. In 1955, when the French Cahiers announced that cinematic pastness had been successfully secured away, Italian Marxism had begun theorizing the persistence of the archaic within the present. Mario Cannella writes about the 1950s, "[b] etween 1948 and 1955 it was possible to become aware of a failing: now that the ruling class that had favored fascism was back in power, there returned, in its most archaic aspects, the culture of Italian conservatism" (10). World War II had not constituted a historical caesura, and liberation from Fascism had merely played for affect. The advent of progress had been ceremonial, sanctioned from above and by decree but untraceable when tested vis-à-vis the concreteness of society's political and economic structures. By way of Gramsci, Italians call this condition "trasformismo," a term that 
conveys distrust in progress and in the contemporary. Accordingly, Cinema Nuovo could not but depart from the French enthusiasts, for who not only had the future positively arrived, but the cinema of Italy had provided the gateway. In the 1950 s, Italian Marxist critics required of their national cinema a contemplation of the effects of trasformismo. This did not entail looking onward to an alleged future of progress and cosmopolitan emancipation, but bringing to the fore the archaic aspects of a local state of contemporary affairs. Released one year after Journey to Italy, Luchino Visconti's Senso (1954) met these requirements. Tepidly received by the Cahiers and acclaimed by Aristarco, the film has been thoroughly discussed as the archetypal text of trasformsimo. I shall not contribute to this discussion. I will, however, stay with Visconti, flash-forwarding ten years to the release of Sandra (1965).

By 1965, "European art-cinema" had matured into a global category largely engaged with the formation of visions of modernity. In Sandra, Visconti partly operates within these rules of engagement. In proverbially Viscontian fashion, however, cosmopolitanism and the modern are invoked to connote decay and loss rather than maturity and conquest. Victim of this trajectory of demise is the national specificity of Italian neo-realism, of which Visconti nostalgically revisits the gradual effacement within the totality of "art-cinema" as de-nationalized institution. As if to ascertain whether in 1965 a movement of re-territorialization is historically practicable, Visconti disseminates the film with incursions into localness and the past. Despite the clearly visualized impingement of modernity, neo-realism is tentatively exhumed, or invoked as anachronistic reference, throughout Sandra. In 1954, Aristarco had praised Senso for reconnecting the national cinema with the nation's history. The film had allegedly achieved such reconnection by challenging the reassuring narrative of a historiography based on sharp caesuras rather than on the upsetting persistence of trasformismo. Working along temporal hypotheses similar to Senso, Sandra uses the incoercibility of ancientness and localness to upset the wholesomeness of modernity and cosmopolitanism. I would like to consider a couple of scenes that are germane to this discussion. 
In a pre-credit sequence, the titular Sandra entertains a cosmopolitan crowd during a cocktail party in Geneva, Switzerland, where she leaves with her American husband, Andrew. I call this the "Antonioni section," and in a longer draft of the paper, I go to great pains to explain why. Suffice to say, to the risk of providing a grocery list of Antonionian buzzwords, that Sandra's social alienation, incommunicability, and psychological neuroses are established in this prologue. Also, Visconti strives for the formation of images of subjectivity and memory (one celebrated zoom shot in particular), thus invoking not just Antonioni, but a whole set of conventions that typify the "genre" of European intellectual art films. In fact, the sheer convergence of these thematic and aesthetic markers qualifies the scene as critical parody of art cinema conventions. What gets seemingly caricaturized here is the same existential universalism that Cinema Nuovo had imputed to Journey to Italy. It is the idea that inherent in the modern condition is the transition from the concreteness of the historical space to the indefiniteness of what Deleuze, apropos the landscapes of Antonioni's cinema, calls the "any-space-whatever." Switzerland, and I write this without malice, is the archetypal anyspace-whatever. It represents an abstract space-time dimension whose fragmented components suggest an idea of boundless-ness. Switzerland's proverbial neutrality prevents the country from entering the stream of European history and temporality (Deleuze's grand caesura, World War II, never took place in Switzerland), thereby rendering the place a site of timelessness, a self-sufficient structure incurved into itself but extracted from the stream of historicity.

As a result, when in the sequence following the cocktail party, Sandra leaves Switzerland for her native town of Volterra, in Tuscany, she brings into effect a movement towards history, from an anyspace-whatever to the specificity of geographical, historical, and social space-times. Throughout Sandra's journey to Italy, a number of road signs indicating names of cities emphasize her return to localness. That she goes in the opposite direction of Paris, as one road sign indicates, is geographically logic, but it is also indicative of both her departure from cosmopolitan ambitions and Visconti's own momentary sidetracking of pan-European film culture. Approaching 
a road sign that reads "Florence," on the other hand, evokes a reappropriation of indigenous culture, possibly the nostalgic incursion into the neo-realist myth of Rossellini's 'Paisa' (1946). Upon entering Tuscany, the signs disappear. It is Sandra who now speaks to the husband the names of the Italian localities, as in an effort to reappropriate them, to become identical with them again: Cecina, Volterra, and so forth in a crescendo of localness, down to the Gate of San Francesco and the city's Etruscan Walls. In 1965, of course, Italian neo-realism had been dead ten years, its image as archaic as Volterra's ancient walls. Yet it is arguably a sense of the neo-realist archaic that Visconti exhumes. Thus, Sandra's journey acquires the opposite historiographic significance of the Bergman character's own incursion into Italian soil ten years earlier in Journey to Italy. With this film, Rossellini's transcendental realism had allegedly provided the gateway into modernity. In Sandra, by contrast, Visconti utilizes the passe status of neo-realism in order to defy modernity, seeking a reconnection with ancientness and the incoercible provinciality of localness.

Later in the film, Sandra's brother, Gianni, takes Sandra's husband on a tour of Volterra. Like Sandra had done before, Gianni educates Andrew with Ciceronian competence. Feeding him with names of ancient sites and localities, he continues to extract Andrew from modernity and cosmopolitanism. Here, however, it is loss of ground, de-territorialization, and the triumph of modernity that get sadly ratified. During her journey from Switzerland to Italy, Sandra had navigated effortlessly across lands, devoured distances, and dominated a soil that underneath her feet had remained firm, providing the reliable path along which the motivations of her character had gotten fulfilled. With Gianni and Andrew in Volterra, however, it is soil that devours character, and character that is prey to the ground's infirmity, at best tenuous challenge to the soil's life cycle and geological phenomenology. In Volterra, the earth really trembles, sliding down through the centuries, the soil swallowing into oblivion the town and its ancient history. Standing on the edge of a cliff overlooking centuries of erosion and landslides, Ganni and Andrew resemble the Valastro women of La terra trema, who had stood on the rocks in contemplation 
of another force of nature, the ocean, which, they feared, had swallowed their men. However, while the Valastros can count on the firmness of the soil, of which they become the natural extension and timeless proprietors, Gianni and Andrew stand on a ground that with time vanishes.

Moreover, while in the film's opening section, Visconti had successfully left behind the Antonionian sensibility, marker of modernity and de-territorialization, now modernity and the conventions of contemporary art-cinema impinge on ancientness, revealing the anachronism of an aesthetic tradition that Visconti may exhume but not revive. Visconti's sweeping camera pans, towards and away from the Church of San Giusto and the Camaldoli Abbey, make Volterra look like Aci Trezza. However, the Volterra exteriors are crosscut with shots of Sandra wandering about the palatial home, prey to domestic neuroses that only a year earlier had been the province of Monica Vitti in Antonioni's Red Desert (1964). For these shots, Visconti abandons the pan in favor of the zoom, modernistically resumed to pull us back into Sandra's consciousness and subjectivity. The result is that the Volterra exteriors appear framed as fantasy, posing as utopian and unattainable Visconti's nostalgic return to Aci Trezza and the 1940s.

In 1947, when La terra trema went into production, trasformismo had already been theorized, especially through Gramsci's take on Risorgimento. Yet, the term had neither fully penetrated the vocabulary of Italian politics, nor, most importantly, had it been adopted by Italian Marxism as chief critical category. Until the Communist Left was defeated in the pivotal elections of April 18, 1948, both Gramscianism and neo-realism had been invoked as conveyors of progress. They had provided a line of flight from the old to the new, from the prehistorically regional to the historically national. By 1965, however, history and modernity had proven to have in store but the mere internationalization of trasformismo. In Western Europe, the new had come in the form of a Marshall Plan, the insurance policy that guaranteed the continuation of a process of conservative involution. In the Soviet Union, on the other hand, Stalinism and the invasion of Hungary of 1956 had reverted the country 
to its own Czarist past. Accordingly, Sandra is a modern film because it has the modern contain the archaic, because, like Senso, it utilizes the workings of trasformismo as both representational strategy and dramatis persona. Within the context of post-1960 Italian "art-cinema," a number of filmmakers are preoccupied with theorizing and critiquing modernity in the light of trasformismo. Pasolini, Bertolucci, and the Taviani brothers are eminent examples, besides Visconti. Their worlds may simultaneously contain the past, the present, and the future, and their characters may well be unable to bring to closure a "sensorymotor" trajectory, as Deleuuze would have it. However, one should be careful when positioning these properties under the auspices of a totalizing ethics of cinematic modernity. It would be especially misleading to associate the convergence of different space-time dimensions with the formation of de-territorialized "any-spaces whatever," as postmodernist hermeneutics tends to do. This approach may be useful for an understanding of Antonioni and the later films of Rossellini, who clearly strive for the universal. The emplotment of trasformismo, on the other hand, is one example in which a synchronic perspective is not wedded to the tenets of phenomenological totality, but rather to the analysis of a locally contingent state of historical and political affairs.

\section{Bibliografia}

BAZIN, André. What is Cinema? Volume II. Trans. Hugh Gray. Berkeley: U of California P, 1967.

CANNELLA, Mario. "Ideology and Aesthetic Hypothesis in the Criticism of Neo-Realism." Screen. 14:4. (1973/1974). 5-60.

ROHMER, Eric. "The Land of Miracles." Cahiers du Cinéma: The 1950s - Neo'Realism, Hollywood, New Wave. Ed. Jim Hillier. Cambridge: Harvard UP, 1995. 205-208.

RIVETTE, Jacques. "Letter on Rossellini." Cahiers du Cinéma: The 1950s - Neo-Realism, Hollywood, New Wave. Ed. Jim Hillier. Cambridge: Harvard UP, 1995. 205-208. 